DOI: https://doi.org/10.32839/2304-5809/2021-11-99-82

УДК 336.27

Західна О.Р., Круглякова В.В., Біда М.С. Львівський національний університет імені Івана Франка

\title{
ВПЛИВ ДЕРЖАВНОГО БОРГУ НА НАЦІОНАЛЬНУ ЕКОНОМІКУ
}

\begin{abstract}
Анотація. В статті розкрито сутність поняття державного боргу, а також визначено його негативні та позитивні наслідки для національної економіки. Висвітлено основні функції державного боргу як економічної категорії. Розглянуто структуру державного боргу та охарактеризовано її складові: внутрішній та зовнішній державний борг. Висвітлено причини виникнення та зростання державного боргу в Україні. Розглянуто та проаналізовано динаміку та склад державного боргу України на кінець 2016-2020 років. Також досліджено динаміку співвідношення державного та гарантованого державою боргу за останні п’ять років і проаналізовано аналогічні дані на кінець вересня 2021 року. Виявлено основні причини, які повпливали на різке збільшення державного боргу у 2020 році, а також запропоновано заходи, що посприяють зменшенню дефіциту державних коштів.
\end{abstract}

Ключові слова: державний борг, валовий внутрішній продукт, гарантований державою борг, дефріцит державного бюджету, національна економіка.

Zakhidna Oksana, Kruhlyakova Vira, Bida Marta Ivan Franko National University of Lviv

\section{THE INFLUENCE OF PUBLIC DEBT ON THE NATIONAL ECONOMY}

Summary. One of the most important problems of Ukraine's economy today should be considered the lack, but rather the deficit, of funds needed for the state to perform its functions. In such a situation, the state is forced to mobilize additional funds to cover its expenses, this is how public debt arises. Since public debt is an important component of the national economy, it has a significant impact on its elements, which indicates the importance of stabilizing the financial system of Ukraine through effective debt management. This article fully reveals the essence of the concept of public debt: the definition of both domestic and for-eign scientists and researchers is analyzed. It is determined that despite the negative consequences, public debt can have a positive impact on the national economy, if you use the provided loans for investment purposes. The study found that as an economic category, public debt performs two main functions - fiscal and regulatory. The structure of public debt is considered, it is noted that it can be divided into two components: public external debt and public domestic debt. These concepts are characterized and the differences between them are determined. The article stipulates that domestic public debt is more profitable because it poses fewer threats to the national economy. Also, this paper reflects the main causes of public debt in Ukraine. The dynamics of the absolute size of the public debt of Ukraine and the ratio of its value to the nominal GDP for the last five years are considered. It was revealed that during the studied period the volume of public debt of Ukraine tends to increase. It is determined that the total public debt includes public debt and state-guaranteed debt, the difference between these categories is determined. The dynamics of change and the ratio of state and state-guaranteed debt are analyzed. The ratio of public and state-guaranteed debt as of the end of September 2021 has been studied. The reasons that caused the increase in public debt in 2020 are analyzed. The article proposes a number of specific measures that will help reduce the risk of significant debt threats, which in turn negatively affect the national economy of Ukraine.

Keywords: public debt, gross domestic product, state-guaranteed debt, state budget deficit, national economy.

Постановка проблеми. Виникнення державного боргу зумовлено тим, що держава не завжди має власні кошти в достатній кількості для фрінансування державного бюджету, що спонукає її до використання позик. Якщо, використовувати такі кошти ефективно, спрямовуючи їх на інвестиційні проєкти, то це може стати позитивним чинником економічного зростання Проте, у разі неедективного використання такі заборгованості перетворюються у тяжкий тягар для бюджету і країни загалом. Саме тому постає завдання дослідження впливу державного боргу на національну економіку та його ефективного управління.

Аналіз останніх досліджень і публікацій. Питання впливу державного боргу на національну економіку досліджували у своїх працях такі вітчизняні та зарубіжні вчені: Агапова Т. Базилевич В., Брю С., Макконелл К., Сергін С., Федосов В., Юрій С. та багато інших.

Виділення не вирішених раніше частин загальної проблеми: На сьогоднішній день, державний борг є невід'ємною частиною будь- якої держави з ринковою економікою. Від його ефрективного управління залежить економічна ситуація в країні. Незважаючи на велику кількість раніше проведених досліджень дана тема залишається актуальною, враховуючи появу нових фракторів, які повпливали на збільшення державного боргу.

Мета статті. Головною метою даної статті $є$ дослідження поняття державного боргу та його впливу на національну економіку, а також аналіз динаміки його зміни.

Виклад основного матеріалу. Незважаючи на те, що існування в економіці дефіциту грошових коштів є об'єктивним фрактором, він є однією 3 найголовніших проблем економіки України. Державний борг є складовою частиною економіки країни, відповідно до цього має великий вплив на її елементи. Це, в свою чергу, говорить про важливість стабілізування фонансової системи України за допомогою дієвого управління запозиченнями.

Для кращого розуміння пропонуємо розглянути дефініцію поняття державного боргу більш 
детально, адже кожен науковець трактує його по-різному.

Наприклад, К. Макконелл, С. Брю пояснюють сутність державного боргу як загальну суму всіх дефіцитів і позитивних сальдо федерального бюджету, накопичену за всю історію країни [1, с. 842].

У свою чергу такі науковці, як П.А. Самуельсон і В.Д. Нордхаус, говорять, що державний борг - це загальна сума боргових зобов'язань уряду у формі облігацій і короткострокових позик [2, с. 237].

Красільнікова К. В. інтерпретує державний борг як суму заборгованості держави за випущеними і не погашеними внутрішніми державними запозиченням, а також суму фінансових зобов'язань до іноземних кредиторів на певну дату, включаючи видані гарантії за кредитами, що надають місцевим органам влади, державним підприемствам, іноземним постачальникам тощо [3, с. 167].

Згідно 3 Бюджетним кодексом України, державний борг - це загальна сума боргових зобов'язань держави 3 поверненням отриманих та непогашених кредитів (позик) станом на звітну дату, що виникають внаслідок державного запозичення [4].

Наявність державного боргу, його розміри, розміщення і методи погашення прямо чи опосередковано впливають майже на всі сторони економічного життя держави, такі як: дефіцит державного бюджету, розмір грошової маси в обігу, що визначає темпи інфляції, звуження чи розширення сукупного попиту і пропозиції. Це робить державний борг не просто засобом залучення коштів для фрінансування державних потреб, але й важливим інструментом фінансової політики держави, невірне використання якого може призвести до суттєвих ускладнень, чи навіть до фінансової кризи [5, с. 29-30].

Незважаючи на негативні наслідки існування державного боргу деякі вчені загострюють увагу на його позитивному впливі на національну економіку, що проявляється у здійснені більших сукупних витрат порівняно 3 виробленим національним доходом, можливості фінансувати інвестиції, що не забезпечуються внутрішніми заощадженнями [6, с. 332].

Вплив державного боргу на стан фінансової безпеки держави вимагає підвищеної уваги з боку спеціалістів 3 огляду на те, що сучасний етап фрормування боргових зобов'язань характеризується низкою специфічних особливостей. По-перше, в умовах глобалізації фрінансових потоків, здійснення політики необмеженої відкритості щодо іноземних інвестицій, певною мірою відбувається нівелювання меж між внутрішнім і зовнішнім боргом. По-друге, дедалі яскравіше окреслюється наочно посилення взаємозв'язку державних зобов'язань і зобов'язань господарюючих суб'єктів [5, с. 30].

Розглянемо структуру державного боргу: його можна поділити на зовнішній та внутрішній. Зовнішній державний борг - це заборгованість держави перед іноземними кредиторами, а внутрішній заборгованість держави перед власниками державних цінних паперів та іншими кредиторами.

Наукові дослідження вчених обгрунтували, що зовнішній борг являється менш вигідним та має більше загроз, ніж внутрішній. Це можна пояс- нити тим, що сплачення відсотків за внутрішнім боргом здійснюеться всередині країни і при умові помірних ставок за відсотком - борг в майбутньому не перетворюеться на тягар [7, с. 90].

Причинами виникнення та зростання державного боргу в Україні є:

- дефіцит державного бюджету та постійний дефіцит платіжного балансу країни;

- залучення коштів нерезидентів для підтримки стабільного стану національної валюти;

- домінування швидкості зростання державних видатків над зростанням державних доходів [8, с. 122-123].

Незважаючи на теоретичні напрацювання на практиці не завжди вдається використати їх в повній мірі, оскільки існують інші обставини та проблемні моменти.

Так, розвиток економіки України сьогодні відбувається у складних, неординарних умовах кризи державних фрінансів і грошово-кредитної системи, значного послаблення фінансової стійкості й рівноваги, серйозних внутрішніх і зовнішніх викликів. Усе це знаходить відображення в падінні ВВП, загальному дефіциті торговельного й платіжного балансів, фрінансових ресурсів на макро- й мікрорівні, зростанні інфляції, бюджетного дефіщиту та державного боргу. Для виходу з гострої кризи, реформування та реструктуризації економіки й фінансів необхідні рішучі дії та відповідні обсяги грошових ресурсів [9, с. 79].

Пропонуемо розглянути динаміку абсолютного розміру державного боргу України та відношення його величини до ВВП за останні 5 років (табл. 1).

Аналізуючи табл. 1, можна сказати, що порівняно з 2016 роком державний борг у 2020 зріс на 622177 млн. Зовнішній борг за п'ять років зріс всього на 278906,1 млн, в той час як внутрішній - на 343270,8 млн.

Як видно з таблиці, з 2016 року існуе тенденщія до зменшення співвідношення державного боргу до ВВП. На кінец 2017 року цей показник становив 71,8\%, у 2018 - 60,9\%, а у 2019 показник знизився до $50,3 \%$.

Проте, у 2020 році ця тенденція змінилася. Якщо порівняти сукупний державний борг у 2019 і 2020 рощі, то помітно, що темп приросту цьго показника став $27,7 \%$, а він сам набув найбільшого значення за досліджуваний період, тобто за останні п'ять років, і склав 2551936 млн грн. Звичайно, на таку динаміку у більшій мірі повпливала ситуація з пандемією COVID-19 в Україні та й у всьому світі.

Згідно 3 інфрормацією від Рахункової палати, бюджет 2020 р. мав майже 639 млрд грн (37\% фpiнансового ресурсу держбюджету) надходжень від державних запозичень. Цей обсяг майже на $66 \%$ перевищив витрати на погашення державного боргу, що і спричинило його збільшення. Також у Рахунковій палаті зазначили, що станом на 2020 р. кожен українець заплатив по 3 тис. грн. за обслуговування державного боргу [11].

Варто наголосити, що сукупний державний борг включає в себе державний та гарантований державою борг. Відмінність державного та гарантованого державою боргу полягає в тому, що гарантований державою борг надається не безпосередньо для держави, а для підприемств-резидентів під державні гарантії [8, с. 123]. Пропонуємо 
Динаміка та склад державного боргу України на кінець 2016-2020 років

\begin{tabular}{|c|c|c|c|c|c|}
\hline Рік & $\begin{array}{c}\text { Валовий } \\
\text { внутрішній } \\
\text { продукт (ВВП), } \\
\text { млн грн }\end{array}$ & $\begin{array}{c}\text { Сукупний } \\
\text { державний борг, } \\
\text { млн грн }\end{array}$ & $\begin{array}{c}\text { Зовнішній борг, } \\
\text { млн грн }\end{array}$ & $\begin{array}{c}\text { Внутрішній борг, } \\
\text { млн грн }\end{array}$ & $\begin{array}{c}\text { Відношення } \\
\text { загального } \\
\text { державного } \\
\text { боргу до ВВП, \% }\end{array}$ \\
\hline 2016 & 2383182 & 1929759 & 1240028,7 & 689730,0 & $81,0 \%$ \\
\hline 2017 & 2982920 & 2141674 & 1374995,5 & 766678,9 & $71,8 \%$ \\
\hline 2018 & 3558706 & 2168627 & 1397217,8 & 771409,3 & $60,9 \%$ \\
\hline 2019 & 3974564 & 1998275 & 1159221,6 & 839053,8 & $50,3 \%$ \\
\hline 2020 & 4194102 & 2551936 & 1518934,8 & 1033000,8 & $60,8 \%$ \\
\hline
\end{tabular}

Джерело: розроблено авторами за даними [10]

Державний та гарантований державою борг України

Таблиця 2 за останні 5 років, млрд дол. США

\begin{tabular}{|l|c|c|c|c|c|}
\hline & $\mathbf{3 1 . 1 2 . 2 0 1 6}$ & $\mathbf{3 1 . 1 2 . 2 0 1 7}$ & $\mathbf{3 1 . 1 2 . 2 0 1 8}$ & $\mathbf{3 1 . 1 2 . 2 0 1 9}$ & $\mathbf{3 1 . 1 2 . 2 0 2 0}$ \\
\hline $\begin{array}{l}\text { Загальна сума державного та } \\
\text { гарантованого державою боргу }\end{array}$ & 70,97 & 76,31 & 78,32 & 84,37 & 90,25 \\
\hline Державний борг & 60,71 & 65,33 & 67,19 & 74,36 & 79,90 \\
\hline Внутрішній борг & 24,66 & 26,84 & 27,49 & 35,02 & 35,39 \\
\hline Зовнішній борг & 36,05 & 38,49 & 39,70 & 39,34 & 44,51 \\
\hline Гарантований державою борг & 10,26 & 10,97 & 11,13 & 10,00 & 10,35 \\
\hline Внутрішній борг & 0,70 & 0,47 & 0,37 & 0,39 & 1,14 \\
\hline Зовнішній борг & 9,56 & 10,50 & 10,76 & 9,61 & 9,21 \\
\hline
\end{tabular}

Джерело: розроблено авторами за данили [12]

розглянути динаміку співвідношення державного та гарантованого державою боргу (табл. 2).

Як видно 3 таблиці 2, обсяги державного боргу значно перевищують обсяги гарантованого державою боргу. Так, на кінец 2016 року державний борг складав 85,5\% від сукупного державного боргу України в той час як гарантований - 14,5\%. У 2020 році в той самий період частка державного боргу склала вже $88,5 \%$, а гарантованого - 11,5\% відповідно.

Протягом грудня 2020 року сума державного та гарантованого державою боргу Укра- їни збільшилась у гривневому еквіваленті на 153,64 млрд грн та у доларовому еквіваленті державний та гарантований державою борг збільшився на 6,01 млрд дол. США [12].

Згідно 3 даними Міністерства фонансів України [13] станом на 30 вересня 2021 року державний та гарантований державою борг України становив 2 445,52 млрд грн або 92,02 млрд дол. США.

Державний борг України становив 2 168,82 млрд грн (88,69\% від загальної суми державного та гарантованого державою боргу) або 81,61 млрд дол. США, а гарантований державою

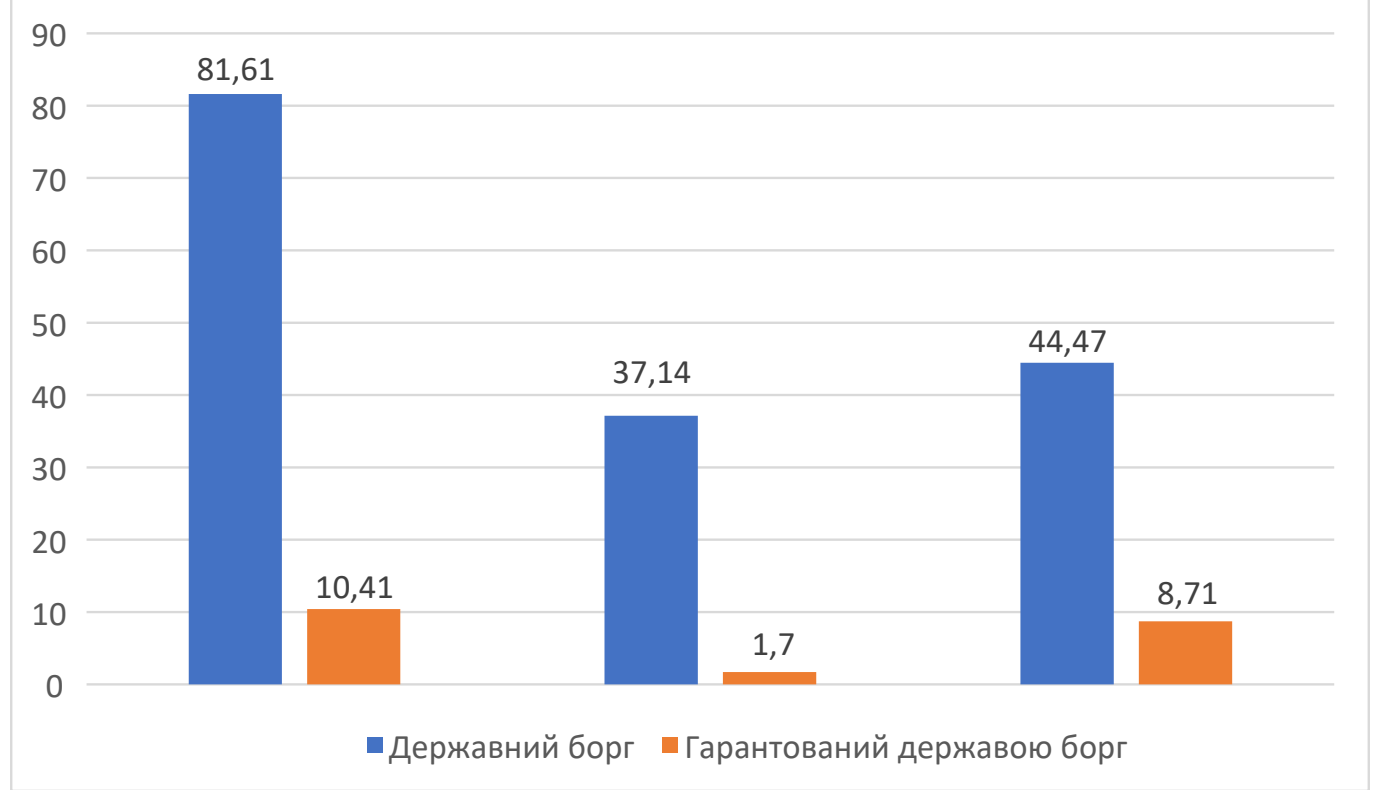

Рис. 1. Співвідношення показників державного та гарантованого державою боргу станом на 30.09.2021, млрд дол. США

Джерело: розроблено авторами за даними [14] 
борг України становив 276,70 млрд грн $(11,31 \%)$ або 10,41 млрд дол. США.

Протягом вересня 2021 року сума державного та гарантованого державою боргу України зменшилась у гривневому еквіваленті на 39,83 млрд грн та у доларовому еквіваленті державний та гарантований державою борг зменшився на 0,51 млрд дол. США (рис. 1).

Як бачимо з проведеного аналізу, в Україні спостерігається тенденція зростання обсягу державного боргу, саме тому важливо наголосити на небезпеці формування суттевих боргових загроз національній економіці. Для того, що зменшити цей фактор, пропонуемо запроваджувати такі заходи:

- здійснення контролю за загальним обсягом державного боргу України задля запобігання його зростання за безпечну межу;

- залучати кошти від приватних бізнес-структур для фінансування державного боргу України у вигляді облігацій з низькою відсотковою став- кою та мінімальною сумою для отримання податкових пільг;

- надавати кредити в короткостроковий період під високі відсотки для погашення наявних боргів в довгостроковому періоді.

Висновки і пропозиції. Підводячи підсумки дослідження, можна сказати, що у наданому етапі Україна має надмірне боргове навантаження, а дефріџит грошових коштів набув свого рекордного значення у 2020 рощі і становив - 90,25 млрд дол. США. Як наслідок - уповільнене економічне зростання та зменшення доходів населення. Причиною цьому $\epsilon$ неготовність економіки до непередбаченої коронакризи, а також тяжке політичне, а 3 тим і фрінансове становище в країні. В подальшому для забезпечення фрінансової стабільності уряд має сформувати ефективну систему управління державним боргом, що передбачає розробку довгострокової бюджетної стратегії, стимулювання ділової активності, контроль за обсягом і динамікою державного боргу і насамперед використання запозичень на цілі розвитку.

\section{Список літератури:}

1. Макконнелл К., Брю С. Экономикс: Принципы, проблемы и политика. Бишкек, 2016. 1028 с.

2. Самуэльсон П., Нордхаус В. Экономика. Санкт-Петербург : Диалектика, 2020. 1325 с.

3. Арутюнян С. С., Добриніна Л. В., Красільнікова К. В. Фінансовий ринок : навчальний посібник для студентів ВНЗ. Київ, 2018. 484 с.

4. Бюджетний Кодекс України від 29.09.2021 (Відомості Верховної Ради України (ВВР), 2010, № 50-51, ст. 572). URL: https://zakon.rada.gov.ua/laws/show/2456-17\#Text

5. Носова Т. І. Яновський Д. Л. Проблематика державного боргу України та можливость її рішення. Трансфбормація ббінансової систели та обліку в уловах інноваційної глокалізацї національної еконоліки : наук.практ. конфр. (Одеса, 26-28 жовтня. 2018 р.) Одеса, 2018. С. 29-30.

6. Старостенко Г. Г., Онишко С. В., Поснова Т. К. Національна економіка. Київ : Ліра, 2016. 432 с.

7. Ведмідь М. О., Дорошенко О. О. Державний борг України: причини та наслідки для національної економіки. Секиія навчально-наукового інституту еконоліки, управління, права та інфборлаційних технологій : матеріали студ. наук. конфр. (Полтава, 13 травня 2021 р.). Полтава, 2021. С. 90-92.

8. Подаков Є. С. Державний борг України та його вплив на економіку країни. Публічне управління та адліністрування у процесах еконолічних рефборл : матеріали наук.-практ. конф. (Херсон 18-19 квітня 2019 р.). Херсон, 2019. С. 122-124.

9. Паливода П. В. Проблематика фрормування та обслуговування державного боргу України. Вісник Київського інституту бізнесу та технологій. 2017. № 1. С. 78-81.

10. Державний борг України. Міністерство фрінансів України. URL: https://index.minfin.com.ua/ua/finance/ debtgov/ (дата звернення: 07.11.2021).

11. Шрамко Ю. Державний борг України зріс на 7\%. Інформаційне агентство «Українські Національні новини». URL: https://www.unn.com.ua/uk/news/1914109-derzhborg-ukrayini-u-2020-rotsizris-na-7 (дата звернення: 07.11.2021).

12. Держаний борг та гарантований державою борг. Міністерство фінансів України. URL: https://mof.gov.ua/uk/ derzhavnij-borg-ta-garantovanij-derzhavju-borg (дата звернення: 08.11.2021).

13. Інформаційна довідка щодо державного та гарантованого державою боргу України (станом на 30.09 .2021$).$ Міністерство фрінансів України. URL: https://mof.gov.ua/storage/files/\%D0\%86\%D0\%BD\%D1\%84\%D0\%BE\% D 1\%80\%D0\%BC\%D0\%B0\%D 1\%86\%D 1\%96\%D1\%8F\%20\%D0\%BF\%D0\%BE\%20\%D0\%B1\%D0\%BE\%D $1 \%$ 80\%D0\%B3\%D1\%83\%20\%D0\%BD\%D0\%B0\%2030_09_2021.docx (дата звернення: 08.11.2021).

14. Державний та гарантований державою борг України за станом на 30.09.2021. Міністерство фрінансів У країни. URL: https://mof.gov.ua/storage/files/\%D0\%91\%D0\%BE\%D1\%80\%D0\%B3\%2030_09_2021\%20\%D0\% BC\%D0\%BB\%D1\%80\%D0\%B4.xlsx (дата звернення: 08.11.2021).

\section{References:}

1. McConnell, C. R. and Brue, S. L. (2016) Ekonomikc: Printsipy, problemy i politika [Economics: Principles, Problems and Policies]. Bishkek.

2. Samuel'son P., Nordkhaus V. (2020) Ekonomika [Economic], Sankt-Peterburg: Dialektika. (in Russian)

3. Arutiunian S. S., Dobrynina L. V., Krasilnikova K. V. (2018) Finansovyi rynok [Financial market]. Kyiv. (in Ukrainian)

4. Budget Code of Ukraine dated 10.11.2021 (Vidomosti Verkhovnoi Rady Ukrainy (VVR), 2010, № 50-51, p. 572). Retrieved from: https://zakon.rada.gov.ua/laws/show/2456-17\#Text

5. Nosova T. I., Yanovskyi D. L. (2018) Problematyka derzhavnoho borhu Ukrainy ta mozhlyvost y ii rishennia [The problem of public debt of Ukraine and the possibility of its solution]: Proceedings of the Transformatsiia finansovoi systemy ta obliku v umovakh innovatsiinoi hlokalizatsii natsionalnoi ekonomiky (Ukraine, Odesa, October 26-28, 2018), Odesa, pp. 29-30.

6. Starostenko H. H., Onyshko S. V., Posnova T. K (2016) Natsionalna ekonomika [National economy]. Kyiv: Lira. (in Ukrainian)

7. Vedmid M. O., Doroshenko O. O. (2021) Derzhavnyi borh Ukrainy: prychyny ta naslidky dlia natsionalnoi ekonomiky [Ukraine's public debt: causes and consequences for the national economy]: Proceedings of the sektsiia navchalno-naukovoho instytutu ekonomiky, upravlinnia, prava ta informatsiinykh tekhnolohii (Ukraine, Poltava, March 13, 2021), Poltava, pp. 90-92. 
8. Podakov Ye. S. (2019) Derzhavnyi borh Ukrainy ta yoho vplyv na ekonomiku krainy [Derzhavnyi borh Ukrainy ta yoho vplyv na ekonomiku krainy]: Proceedings of the publichne upravlinnia ta administruvannia u protsesakh ekonomichnykh reform (Ukraine, Kherson March 18-19, 2019), Kherson, pp. 122-124.

9. Palyvoda P. V. (2017) Problematyka formuvannia ta obsluhovuvannia derzhavnoho borhu Ukrainy [Problems of formation and servicing of the state debt of Ukraine]. Bulletin of the Kyiv Institute of Business and Technology, vol. 1 , pp. $78-81$.

10. Public debt of Ukraine. Ministry of Finance of Ukraine. Retrieved from: https://index.minfin.com.ua/ua/finance/ debtgov/ (accessed 7 November 2021).

11. Shramko Y. Public debt of Ukraine increased by 7\%. Ukrainian National News Agency. Retrieved from: https://www.unn.com.ua/uk/news/1914109-derzhborg-ukrayini-u-2020-rotsizris-na-7 (accessed 7 November 2021).

12. Public debt and state-guaranteed debt. Ministry of Finance of Ukraine. Retrieved from: https://mof.gov.ua/uk/ derzhavnij-borg-ta-garantovanij-derzhavju-borg (accessed 8 November 2021).

13. Information on the state and state-guaranteed debt of Ukraine (as of September 30, 2021) Ministry of Finance of Ukraine. Retrieved from: https://mof.gov.ua/storage/files/\%D0\%86\%D0\%BD\%D1\%84\%D0\%BE\% D1\%80\%D0\%BC\%D0\%B0\%D1\%86\%D1\%96\%D1\%8F\%20\%D0\%BF\%D0\%BE\%20\%D0\%B1\%D0\%BE\%D1\%80\% D0\%B3\%D1\%83\%20\%D0\%BD\%D0\%B0\%2030_09_2021.docx (accessed 8 November 2021).

14. State and state-guaranteed debt of Ukraine as of September 30, 2021. Ministry of Finance of Ukraine. Retrieved from: https://mof.gov.ua/storage/files/\%D0\%91\%D0\%BE\%D1\%80\%D0\%B3\%2030_09_2021\%20\%D0\% BC\%D0\%BB\%D1\%80\%D0\%B4.xlsx (accessed 8 November 2021). 